\title{
Predictive Model for Strawberry Bud Weevil (Coleoptera: Curculionidae) Adults in Strawberry Fields
}

\author{
N. J. BOSTANiAn, ${ }^{1}$ M. BINNS, ${ }^{2}$ J. KOVACH, ${ }^{3}$ G. RACETTE, ${ }^{1}$ and G. MAILLOUX ${ }^{4}$
}

\begin{abstract}
Environ. Entomol. 28(3): 398-406 (1999)
ABSTRACT Three different sampling methods (sweep net, D-Vac, tapping into a carton container) were evaluated for Anthonomus signatus Say in strawberry fields. The results suggest that sampling with a sweep net reflects population numbers best. A predictive model for adult abundance was developed to describe and predict population build-up. The strawberry fields used in the study were in their 2 nd yr of production. Overwintering adults generally begin to appear in a strawberry field $\approx 300$ cumulatitive degree-days (DD) calculated from 1 April at temperatures above $0^{\circ} \mathrm{C}$. These weevils attain maximum abundance anywhere from 500 to $670 \mathrm{DD}$. Within that interval, a treatment with cypermethrin or chlorpyriphos was effective against this pest. The summer generation attained maximum abundance anywhere from 1,250 to 1,650 DD. A treatment with chlorpyriphos at 1,679 DD reduced the summer generation of weevils and decreased clipped buds in the field the following year.
\end{abstract}

KEY WORDS Anthonomus signatus, predictive model, adult abundance, management

THE STRAWBERRY BUD weevil, Anthonomus signatus Say, is 1 of 2 key insect pests of strawberries in Northeastern North America. The other is the tarnished plant bug, Lygus lineolaris (Palisot du Beauvois). Overwintering weevils have been reported on strawberries from mid-May to the end of June with maximum abundance toward the end of May in Quebec (Rivard et al. 1979). In New York, these events occur $\approx 2$ wk earlier (Kovach et al. 1993).

Decreases in yield can be dramatic depending on cultivar. Losses in Quebec range from 10 to $70 \%$ (Paradis 1979). In New York, strawberry yield reductions range from 50 to $100 \%$ (Schaefers 1978). Early maturing cultivars are more susceptible to injury than late maturing cultivars (Dorval 1938). The biology of this insect was described by Mailloux and Bostanian (1993). They confirmed earlier observations that the insect had 4 distinct nonoverlapping stages of development (egg, larva, pupa, adult) (Clarke and Howitt 1975). Furthermore, Mailloux and Bostanian (1993) showed that a 1:1 sex ratio was prevalent throughout spring and summer. The maximum abundance of each developmental stage was determined in relation to cumulative degree-days (DD). Currrently, monitoring is carried out very early in the spring by counting the number of cut buds per flower cluster per linear meter and comparing this with a tentative action threshold of 2 clipped buds per meter (Kovach et al.

\footnotetext{
${ }^{1}$ Horticulture Research and Development Centre, Agriculture and Agri-Food Canada, Saint-Jean-sur-Richelieu, QC, Canada J3B 3E6.

${ }^{2}$ Eastern Cereal \& Oilseed Research Centre, Agriculture and AgriFood Canada, Ottawa, ON, Canada K2C 1Y2.

${ }^{3}$ New York State Agriculture Experiment Station, Cornell University, Geneva, NY 14456-0462.

${ }^{4}$ Institut de Recherches et de Développement, en Agro-Environnement, Saint-Hyacinthe, QC, Canada J2S 480.
}

1993), although some recent work suggests that this threshold is too low (Pritts et al. 1999). However, as weevil populations increase from zero to threatening numbers within a very short period (Mailloux and Bostanian 1993), management action based on damage alone risks being very late. Because there is no generally accepted sampling technique and the timing of control measures is difficult, many growers make a prophylactic treatment at the onset of buds, to be followed by a 2 nd prophylactic treatment just before bloom.

This study was used to evaluate 3 different sampling techniques to estimate the abundance of this insect. Abundance data were collected to develop a predictive model (based on degree-days) to estimate when adult beetles would first be seen and when peak abundance could be expected to occur. Management control based on the results was then validated using data collected in Quebec and New York during 1994.

\section{Materials and Methods}

Model Development. Field observations were made twice a week from early May to the end of August in 1976 and 1987-1991 in strawberry fields not treated with insecticides. The fields were in their $2 \mathrm{nd}$ yr of production and their sizes ranged from 0.5 to 0.75 ha. They were situated at L'Assomption, Frelighsburg, Lavaltrie (near Montreal), St. Louis de Terrebonne, and St. Augustin (near Quebec city). They represent the major strawberry-growing regions of Quebec.

Eighteen sets of data on strawberries (15 on 'Redcoat' and 3 on 'Bounty') were collected over a period of $15 \mathrm{yr}$ from the above mentioned locations (Table 1 ). Counts were made by walking a W-shaped pattern across the field and collecting samples. The following 
Table 1. Methods, cultivar, and year used to collect data in Quebec, Canada

\begin{tabular}{|c|c|c|c|c|c|}
\hline Series & Method & Location & Year & Cultivar & $\begin{array}{c}\text { No. of } \\
\text { sample units }\end{array}$ \\
\hline $\mathrm{N}_{1}$ & Sweep net & l'Assomption & 1985 & Redcoat & 42 \\
\hline $\mathrm{N}_{2}$ & Sweep net & l'Assomption & 1986 & Redcoat & 22 \\
\hline $\mathrm{N}_{3}$ & Sweep net & l'Assomption & 1987 & Redcoat & 20 \\
\hline $\mathrm{C}_{1}$ & Container tapping & St-Augustin & 1983 & Redcoat & 24 \\
\hline $\mathrm{C}_{2}$ & Container tapping & St-Augustin & 1983 & Bounty & 24 \\
\hline $\mathrm{C}_{3}$ & Container tapping & Lavaltrie & 1984 & Redcoat & 24 \\
\hline $\mathrm{C}_{4}$ & Container tapping & St-Louis de Terrebonne & 1985 & Redcoat & 24 \\
\hline $\mathrm{C}_{5}$ & Container tapping & Frelighsburg & 1986 & Redcoat & 19 \\
\hline $\mathrm{C}_{6}$ & Container tapping & Frelighsburg & 1987 & Redcoat & 21 \\
\hline $\mathrm{C}_{7}$ & Container tapping & Frelighsburg & 1988 & Redcoat & 24 \\
\hline $\mathrm{C}_{8}$ & Container tapping & Frelighsburg & 1989 & Redcoat & 32 \\
\hline $\mathrm{C}_{9}$ & Container tapping & Frelighsburg & 1990 & Redcoat & 25 \\
\hline $\mathrm{C}_{10}$ & Container tapping & Frelighsburg & 1991 & Redcoat & 38 \\
\hline $\mathrm{D}_{1}$ & D-Vac & l'Assomption & 1981 & Redcoat & 34 \\
\hline $\mathrm{D}_{2}$ & D-Vac & l'Assomption & 1981 & Bounty & 33 \\
\hline $\mathrm{D}_{3}$ & D-Vac & l'Assomption & 1982 & Redcoat & 41 \\
\hline $\mathrm{D}_{4}$ & D-Vac & l'Assomption & 1982 & Bounty & 41 \\
\hline $\mathrm{D}_{5}$ & D-Vac & Frelighsburg & 1976 & Redcoat & 32 \\
\hline
\end{tabular}

3 sampling techniques were used: (1) 200 suctions with a D-Vac insect aspirator (D-Vac, Riverside, CA). (2) Two hundred sweeps with a $71 \mathrm{~cm}$ long heavy duty muslin insect net. That was D-shaped and had a $38 \mathrm{~cm}$ diameter. (3) Tapping 100 flower clusters twice each over a carton container $(500 \mathrm{ml}$ capacity and $10 \mathrm{~cm}$ diameter); the number of weevils present was recorded and the weevils were allowed to escape.

No samples were recorded from the edges of the fields, and all sampling was done between 10.00 and 13.00 hours on sunny days. In 2 of the sets, replicate sets of 100 container tappings were taken to assess

Fig. 1. Data from the 3 sampling techniques (C, container tapping; N, sweep net; D, D-Vac). 
Table 2. Fitted parameters of the abundance model

\begin{tabular}{|c|c|c|c|c|c|c|c|c|}
\hline Series & $\mathrm{M}_{1}$ & $\mu_{1}$ & $\gamma_{1}$ & $\begin{array}{c}\theta_{1} \\
\left(\times 10^{3}\right)\end{array}$ & $\mathrm{M}_{2}$ & $\mu_{2}$ & $\gamma_{2}$ & $\begin{array}{c}\theta_{2} \\
\left(\times 10^{3}\right)\end{array}$ \\
\hline $\mathrm{N}_{1}$ & 69.2 & 429 & 28.1 & 5.67 & 73.7 & 1197 & 218 & 5.53 \\
\hline $\mathrm{N}_{2}$ & 65.5 & 428 & 58.9 & 6.31 & 257 & 1467 & 407 & 96.9 \\
\hline $\mathrm{N}_{3}$ & 37.1 & 451 & 58.1 & 4.49 & 73.7 & 1185 & 661 & 7.62 \\
\hline AllN & 49.8 & 43.3 & 40.9 & 5.07 & 56.2 & 1230 & 213 & 6.50 \\
\hline $\mathrm{C}_{1}$ & 127 & 483 & 6.83 & 12.6 & 484 & 1374 & 405 & 9.04 \\
\hline $\mathrm{C}_{2}$ & 13.7 & 485 & 36.8 & 11.0 & 53.5 & 1306 & 871 & 9.79 \\
\hline $\mathrm{C}_{3}$ & 134 & 670 & 27.0 & 33.4 & 252 & 1456 & 152 & 58.8 \\
\hline $\mathrm{C}_{4}$ & 90.3 & 581 & 66.1 & 8.20 & 606 & 1500 & 560 & 84.3 \\
\hline $\mathrm{C}_{5}$ & 25.1 & 533 & 97.1 & 6.23 & 137 & 1467 & 219 & 75.2 \\
\hline $\mathrm{C}_{6}$ & 13.3 & 450 & 45.8 & 4.41 & 202 & 1206 & 119 & 21.0 \\
\hline $\mathrm{C}_{7}$ & 20.8 & 484 & 498 & 3.33 & 93.3 & 1492 & 47556 & 11.9 \\
\hline $\mathrm{C}_{8}$ & 35.9 & 484 & 110 & 3.24 & 61.6 & 1566 & 811 & 5.74 \\
\hline $\mathrm{C}_{9}$ & 25.7 & 416 & 6.01 & 4.45 & 68.6 & 1415 & 7374 & 8.56 \\
\hline $\mathrm{C}_{10}$ & 176 & 578 & 9.73 & 14.1 & 121 & 1480 & 118 & 30.8 \\
\hline$D_{1}$ & 63.7 & 392 & 30306 & 2.04 & 1226 & 1364 & 234 & 32.0 \\
\hline $\mathrm{D}_{2}$ & 127 & 392 & 48634 & 1.43 & 187 & 1361 & 3130 & 7.77 \\
\hline$D_{3}$ & 96.3 & 355 & 13.2 & 6.79 & 80.7 & 1300 & 3594 & 6.99 \\
\hline $\mathrm{D}_{4}$ & 24.4 & 279 & 7390 & 3.76 & 14.5 & 1262 & 4913 & 2.73 \\
\hline$D_{5}$ & 24.3 & 526 & 164 & 3.98 & 2881 & 1395 & 434 & 234 \\
\hline
\end{tabular}

sampling variability. Table 1 summarizes the location, year, cultivar, and number of samples per plot. A sample refers to 200 suctions (D-Vac), 200 sweeps (net sampling), or 100 tappings (tapping into carton containers).

Ambient air temperature data were obtained from Environment Canada weather stations located $<8 \mathrm{~km}$ away from each strawberry field. Cumulative degreedays above $0^{\circ} \mathrm{C}$ from 1 April to the end of August were calculated using the Baskerville and Emin (1969) method.

Various preliminary attempts were made to relate the seasonal abundance data to temperature and precipitation, but temperature was clearly the factor influencing development. The relationship between sample counts and degree-days was initially estimated by smoothing the data (Gaussian kernal method) using Mathcad (Mathsoft 1995) separately for each sample method (container, net, D-Vac). The results indicated so much variability within each method (Fig. 1) that fitting an overall model was deemed inappro- priate except possibly for net sampling. Therefore, the model was fitted to each series of data separately and also to all net samples together.

Numerous abundance models have been suggested for variability of agricultural pest populations throughout the season based on thermal summation units (Niemczyk et al. 1992, Cockfield et al. 1994). We chose to adapt models intended for estimating life histories (Kempton 1979, summarized in Manly 1990). The adaptation was to reduce the model from predicting all life stages to predicting only the adult stage. The derivation of the model for $N(t)$, the total number of adults found at time $t$, follows. Because the data were totals of a large number of suctions, sweeps, or tappings, a Poisson distribution for $N(t)$ was assumed. The goodness-of-fit of the model was assessed by the residual deviance (McCullagh and Nelder 1989). The deviance is comparable to the residual error sum of squares in linear regression, but is dimensionless; if everything fits well, the mean deviance (comparable

Fig. 2. Fitted curves for 3 net tapping series: $\mathrm{N}_{1}, \mathrm{~N}_{2}$, and $\mathrm{N}_{3}$. Square brackets in $\mathrm{N}_{1}$ and $\mathrm{N}_{2}$ indicate 1st and 3rd quartiles of the distribution of spring emergence from cages (Mailloux and Bostanian 1993). 
Table 3. Estimates in cumulative degree days (DD) for the 1st adult emergence in spring and maximum abundance of summer generation

\begin{tabular}{|c|c|c|c|}
\hline Series & $\begin{array}{c}\text { DD for } 1 \\
\text { emergence }\end{array}$ & $\begin{array}{c}\text { DD at } \\
\text { spring peak }\end{array}$ & $\begin{array}{c}\text { DD at } \\
\text { summer peak }\end{array}$ \\
\hline N1 & 274 & 508 & 1282 \\
\hline $\mathrm{N} 2$ & 325 & 487 & 1471 \\
\hline N3 & 346 & 530 & 1244 \\
\hline Mean & 315 & 508 & 1332 \\
\hline Standard error & 37 & 22 & 122 \\
\hline All sweep net data & 307 & 511 & 1311 \\
\hline $\mathrm{Cl}$ & 158 & 484 & 1438 \\
\hline $\mathrm{C} 2$ & 385 & 537 & 1356 \\
\hline C3 & 422 & 672 & 1463 \\
\hline $\mathrm{C} 4$ & 434 & 645 & 1509 \\
\hline C5 & 441 & 601 & 1475 \\
\hline C6 & 360 & 535 & 1238 \\
\hline $\mathrm{C} 7$ & 502 & 587 & 1508 \\
\hline C8 & 404 & 566 & 1639 \\
\hline C9 & 229 & 486 & 1488 \\
\hline $\mathrm{C} 10$ & 237 & 663 & 1523 \\
\hline Mean & 357 & 578 & 1464 \\
\hline Standard error & 111 & 68 & 107 \\
\hline D1 & 338 & 460 & 1388 \\
\hline D2 & 338 & 463 & 1403 \\
\hline D3 & 171 & 426 & 1341 \\
\hline D4 & 224 & 296 & 1393 \\
\hline D5 & 453 & 599 & 1393 \\
\hline Mean & 305 & 449 & 1384 \\
\hline Standard error & 110 & 108 & 24 \\
\hline
\end{tabular}

to the error mean square) should be equal to 1 , and the deviance can be tested as $\chi^{2}$. For the 2 datasets where extra data had been collected (Table 1: $\mathrm{C}_{7}, \mathrm{C}_{10}$ ), a within-date residual deviance was also calculated for comparison. Genstat (1996) was used for all these calculations.

Data for spring emergence of adults from cages reported in Mailloux \& Bostanian (1993) were collected during the same time and at the same location as 4 of the datasets. The data from the emergence cages were compared with the fitted model (based on sample data) around the time of spring emergence to check for consistency.

Derivation of the Abundance Model. The basic lifestage model suggested by Kempton (1979) takes the following form: the probability that an individual is in stage $j$ at time $t$ (i.e., is at that stage, in the field and able to be sampled) can be written as the product of the following: (1) the probability that at time $t$ it has matured to but not passed stage $j$, and (2) the probability that it has not died in the meantime. Because we
Table 5. Deviance goodness-of-fit values for the overall model, and within-date error deviance values where data were available

\begin{tabular}{|c|c|c|c|c|c|c|}
\hline \multirow[b]{2}{*}{ Series } & \multicolumn{3}{|c|}{ Overall } & \multicolumn{3}{|c|}{ Within date } \\
\hline & $\begin{array}{l}\text { Residual } \\
\text { deviance }^{a}\end{array}$ & df & $\begin{array}{c}\text { Mean } \\
\text { deviance }^{b}\end{array}$ & $\begin{array}{l}\text { Residual } \\
\text { deviance }\end{array}$ & $\mathrm{df}$ & $\begin{array}{c}\text { Mean } \\
\text { deviance }\end{array}$ \\
\hline $\mathrm{N}_{1}$ & $73 *$ & 34 & 2.2 & & & \\
\hline $\mathrm{N}_{2}$ & 23 & 14 & 1.7 & & & \\
\hline $\mathrm{N}_{3}$ & 18 & 12 & 1.5 & & & \\
\hline $\mathrm{C}_{1}$ & $106^{*}$ & 16 & 6.7 & & & \\
\hline $\mathrm{C}_{2}$ & 15 & 16 & 0.9 & & & \\
\hline $\mathrm{C}_{3}$ & $33^{*}$ & 16 & 2.1 & & & \\
\hline $\mathrm{C}_{4}$ & $75^{*}$ & 16 & 4.7 & & & \\
\hline $\mathrm{C}_{5}$ & $20^{*}$ & 11 & 1.8 & & & \\
\hline $\mathrm{C}_{6}$ & 19 & 13 & 1.5 & & & \\
\hline $\mathrm{C}_{7}$ & $32 *$ & 16 & 2.0 & $40 *$ & 6 & 6.7 \\
\hline $\mathrm{C}_{8}$ & $110^{*}$ & 24 & 4.6 & & & \\
\hline $\mathrm{C}_{9}$ & $51 *$ & 17 & 3.0 & & & \\
\hline $\mathrm{C}_{10}$ & $148^{*}$ & 30 & 4.9 & 21 & 14 & 1.5 \\
\hline $\mathrm{D}_{1}$ & $159 *$ & 26 & 6.1 & & & \\
\hline $\mathrm{D}_{2}$ & $166^{*}$ & 25 & 6.6 & & & \\
\hline $\mathrm{D}_{3}$ & $163 *$ & 33 & 4.9 & & & \\
\hline $\mathrm{D}_{4}$ & $218 *$ & 33 & 6.6 & & & \\
\hline $\mathrm{D}_{5}$ & $77 *$ & 24 & 3.2 & & & \\
\hline
\end{tabular}

*, Significant $(P<0.05)$ departure from Poisson.

${ }^{a}$ To be tested as chi square (deviance is dimensionless).

${ }^{b}$ Residual deviance divided by degrees of freedom.

are interested only in the adults, "stage $j$ " is the emerging adult, so we rewrite (1) above as follows: (1a) the probability that it has emerged by time $t$.

Two mathematical formulations of this have been mentioned in the literature. In one, the possibility of dying is deemed to begin when the "experiment begins," which here would be 1 April when degreedays $=0$ (Manly 1990, p. 60). In the other, the possibility of dying is deemed to begin when the "individual emerges," which would be after 1 April (Manly 1990, p. 52). Although, in several instances including the version used here, there is no formal difference between the representations, we chose the 2nd as being more appropriate for the weevil data. Thus, an appropriate model has an emergence distribution, defined by the probability density $f(x)$ :

Probability that an individual emerges at time $x$, along with a survival distribution, defined by the probability density $w(t-x)$,

Probability that an individual survives from time $x$ to time $t=w(t-x)$.

Thus, the probability of emerging at time $x$ and then surviving for a further time $(t-x)$ can be written as $f(x)$

Table 4. Control of the strawberry bud weevil on strawberry, 1994

\begin{tabular}{|c|c|c|c|c|c|c|c|c|}
\hline & \multicolumn{6}{|c|}{ Spring treatment } & \multirow{2}{*}{\multicolumn{2}{|c|}{$\begin{array}{c}\text { Summer treatment } \\
\text { Geneva }\end{array}$}} \\
\hline & \multicolumn{4}{|c|}{ Frelighsburg } & \multicolumn{2}{|c|}{ Geneva } & & \\
\hline & No. of berries & Injured, $_{\%}^{a}$ & No. of berries & $\begin{array}{c}\text { Injured }^{b} \\
\%\end{array}$ & No. of berries & $\begin{array}{c}\text { Injured }^{c} \\
\%\end{array}$ & No. of berries & $\underset{\%}{\text { Injured, }}{ }^{d}$ \\
\hline Treated & 627 & 0.5 & 538 & 2.2 & 695 & 0.9 & 695 & 1.6 \\
\hline Control & 691 & 9.1 & 545 & 13.2 & 695 & 5.6 & 695 & 5.6 \\
\hline
\end{tabular}

\footnotetext{
${ }^{a} 10 \mathrm{~d}$ after treatment (Ripcord 400 EC applied on 3 July 1994 [549 DD] at $188 \mathrm{ml} / \mathrm{ha}$ ).

${ }^{b} 26 \mathrm{~d}$ after treatment (Ripcord 400 EC applied on 3 July 1994 [549 DD] at $188 \mathrm{ml} / \mathrm{ha}$ ).

${ }^{c} 17 \mathrm{~d}$ after treatment (Lorsban $4 \mathrm{E}$ applied on 27 May 1994 [566 DD] at 2,336 ml/ha).

${ }^{d} 1 \mathrm{yr}$ after treatment (Lorsban $4 \mathrm{E}$ applied on 22 July 1993 [1679 DD] at 2,356 ml/ha).
} 
Fig. 3. Fitted curves for 6 container tapping series, $C_{1}-C_{6}$. Square brackets in $C_{5}$ and $C_{6}$ indicate 1st and 3rd quartiles of the distribution of spring emergence from cages (Mailloux and Bostanian 1993).

$\times w(t-x)$. When this formula is integrated over values of $x$ less than or equal to $t$, the probability of having emerged and still being alive at time $t$ can therefore be written as

$$
p(t)=\int_{0}^{t} f(x) w(t-x) d x .
$$

This formulation was used for both spring and summer generations. Emergence for the 1st generation refers to emergence from winter diapause, and for the summer generation it refers to emergence from the pupa. Of course, the parameters of the probability density functions are different for spring and for summer.

Several distributions have been proposed for $f(x)$ (e.g., gamma, Gaussian, inverse Gaussian). For the bud weevil, the Gaussian distribution was rejected because it is symmetric. Both gamma and inverse Gaussian were tried, but $f(x)$ represented by the gamma distribution was found to fit the data better. Like Manly (1990, p. 50) we used $w(t)=\exp (-\theta t)$. Thus, the formula for $p(t)$ is

$$
p(t)=\int_{0}^{t} g(\mu, \gamma, x) \exp (-\theta[t-x]) d x,
$$

where $g(\mu, \theta, x)$ is the gamma probability distribution function with mean $\mu$ and exponent $\gamma$ :

$$
g(\mu, \gamma, x)=\frac{\left(\frac{\gamma}{\mu}\right)^{\gamma} x^{\gamma-1} e^{-\frac{\gamma x}{\mu}}}{\Gamma(\gamma)} .
$$

The expression for $p(t)$ in equation 1 can be reparameterized so that the formula for emergence and mortality are mathematically separate.

$$
\begin{aligned}
& p(t)=\int_{0}^{t} \frac{\left(\frac{\gamma}{\mu}\right)^{\gamma} x^{\gamma-1} e^{-\frac{\gamma x}{\mu}}}{\Gamma(\gamma)} e^{-\theta(t-x)} d x \\
& =\left(\frac{\gamma}{\gamma-\mu \theta}\right)^{\gamma} e^{-\theta t} \int_{0}^{t} g(m, \gamma, x) d x
\end{aligned}
$$

where

$$
m=\frac{\gamma \mu}{\gamma-\mu \theta} .
$$

However, for much of the bud weevil data, this formula (equation 2) cannot be used numerically because the emergence probability factor [the integral of $g(m, \gamma, x)]$ is often very small, whereas the other 
Fig. 4. Fitted curves for 4 container tapping series, $\mathrm{C}_{7}-\mathrm{C}_{10}$.

factor is very large, causing unacceptable round-off errors. Therefore, the complete integral of equation 1 had to be approximated by numerical quadrature. Using a 3-point Simpson rule (Abramowitz and Stegun 1972) for each interval between sampling times gave poor precision, especially at the beginning of the season, so the season was divided into 50 intervals, the function estimated by 3-point Simpson rules in each, and interpolated at the sample times.

Based on the above formulation, 1st- $(i=1)$ and 2nd- $(i=2)$ generation adults were modeled using the same basic formulae, but with different parameters: $p\left(t, \mu_{i}, \gamma_{i}, \theta_{i}\right)=\int_{0}^{t} g\left(\mu_{i}, \gamma_{i}, x\right) \exp \left(-\theta_{i}[t-x]\right) d x$

and the complete model for $N(t)$, the total number found at time $t$, is a weighted sum of these.

$$
N(t)=M_{1} p\left(t, \mu_{1}, \gamma_{1}, \theta_{1}\right)+M_{2} p\left(t, \mu_{2}, \gamma_{2}, \theta_{2}\right)
$$

The parameters to be fitted are as follows: $\mu_{\mathrm{i}}=$ mean of the emergence distribution in generation $i, \gamma_{i}=$ exponent parameter of the emergence distribution for 
Fig. 5. Fitted curves for 5 D-Vac series: $D_{1}-D_{5}$.

generation $i, \theta_{\mathrm{i}}=$ mortality parameter for generation $i, M_{\mathrm{i}}=$ constants, 1 for each generation.

Model Validation. The individual fitted models were used to estimate key pest management indicators of abundance: time (degree-days) of appearance of 1 adult in spring, time of peak spring abundance, and time of peak summer abundance. In 1994, 2 of these indicators (peak spring and summer abundance) were evaluated in Frelighsburg, Quebec, and Geneva, NY. A 3-yr-old (2nd yr of production) cultivar 'Glooscap' strawberry plot was used in Quebec and a similar but slightly larger plot containing 'Earliglow', 'Allstar', and 'Honeoye' was used in New York. At each location, the plots were divided such that one half was treated according to the model, and the other half was left untreated as a control. At both locations, the control plots received no insecticide treatments for this or any other pest. For the treated plots at Frelighsburg, cypermethrin (Ripcord 400 EC[emulsifiable concentrate] [American Cyanamid, Wayne, NJ]) was applied to $0.05 \mathrm{ha}$ at $188 \mathrm{ml} / \mathrm{ha}$ when $549 \mathrm{DD}$ had been accumulated and berry clusters were examined twice. The 1st observation was $10 \mathrm{~d}$ after treatment and the 2nd was at harvest. At Geneva, chlorpyriphos (Lorsban $4 \mathrm{E}$ [emulsifiable] [Dow-Elanco, Indianapolis, IN] ) was applied to 0.09 ha at $2,336 \mathrm{ml} / \mathrm{ha}$, when 566 DD (27 May) had been accumulated. One hundred berry clusters from each plot were examined for clipped berries at 4 different times (31 May, 2 June, 7 June, and 13 June). Moreover, a summer treatment, at 1,679 DD on 22 July 1993, was also carried out in New York against the summer adults before they entered into reproductive diapause and disappeared on or into the soil. The following year, berries from this treated field were compared with berries from an adjacent control plot.

\section{Results}

The fitted parameters of the abundance model are shown in Table 2. The fitted curves are presented in Figs. 2-5. The lower and upper quartiles of the distribution of spring emergence in cages (Mailloux and Bostanian 1993) are plotted in the figures for $\mathrm{N}_{1}, \mathrm{~N}_{2}$, $\mathrm{C}_{5}$, and $\mathrm{C}_{6}$.

$\begin{array}{cccc}\text { Lower } & \text { Median, } & \text { Upper } \\ & \text { DD } & \text { quartile, DD } \\ \mathrm{N}_{1} & 286 & 320 & 419 \\ \mathrm{~N}_{2} & 367 & 375 & 390 \\ \mathrm{C}_{5} & 411 & 454 & 581 \\ \mathrm{C}_{6} & 375 & 398 & 509\end{array}$

Estimated times for finding the 1st spring adult and for spring and summer peaks are shown in Table 3. The 
expected time in spring for finding the 1st emerging adult (using any one of the 3 sampling techniques) was found to be between 300 and $350 \mathrm{DD}$, although with anything but sweep net the variability was high. Expected time for spring peak ranged from around 450 DD (D-Vac), 510 DD (sweep net) to 580 DD (container tapping), with high variability except with sweep net. Expected time for the summer peak ranged from around 1,310 DD (sweep net), 1,380 DD (DVac) to 1,460 DD (container tapping), with high variability except for D-Vac.

Results from the 2 field evaluations are presented in Table 4 . With a spring treatment in Geneva, $0.9 \%$ of the buds were clipped in the treated plot, $17 \mathrm{~d}$ after treatment, compared with $5.6 \%$ in the untreated control plot. At Frelighsburg, the percentages of clipped berries were $0.5 \%$ in the treated plot and $9.1 \%$ in the untreated control plot $10 \mathrm{~d}$ after treatment. At harvest time these percentages increased to 2.2 and $13.2 \%$, respectively. In the summer treated plot $(1,679 \mathrm{DD})$, $1.3 \%$ of the berries were clipped, the following year in Geneva, whereas, in the control plot the percentage of clipped berries was $5.6 \%$.

\section{Discussion}

Fitting the Model. Sample estimates of population sizes varied considerably among the series of data. Maximum values for 100 container tappings ranged from $<10\left(\mathrm{C}_{2}\right)$ to $>60\left(\mathrm{C}_{4}\right)$ among spring generation data, and from $<10\left(\mathrm{C}_{5}\right)$ to around $200\left(\mathrm{C}_{1}\right)$ among summer generation data. In some datasets the peak spring generation densities were much larger than the summer ones (e.g., $\mathrm{N}_{2}$ ), in some they were similar (e.g., $\mathrm{C}_{4}, \mathrm{C}_{8}$ ), and in others the peak summer densities were much larger (e.g., $\mathrm{C}_{1}, \mathrm{C}_{2}$ ). It is not surprising therefore that the fitted parameter values varied greatly from one dataset to another.

The 2nd-generation data seemed to fit the model better than the 1st-generation data (Figs. 2-5). In the spring, the distribution is likely to be more patchy than in the summer because of adults emerging not only from the strawberry field but also from surrounding fields and brush. There was much variability in the data: samples taken only a few degree-days apart from each other occasionally provided greatly differing estimates of abundance, which could not be accounted for by any reasonable model (for example, $D_{2}$ between 500 and $900 \mathrm{DD}$, and $\mathrm{C}_{5}$ around 1,500 DD). This variabilty is reflected in the goodness-of-fit tests for the models (Table 5). The D-Vac data appear to be especially variable. The sweep net data fitted better than the container tapping data, but the larger number of net sweeps (200) than container tappings (100) may account for that. In 2 of the datasets where container tapping was used, it was possible to estimate "within date" variability (Table 5). Comparison with the Poisson model indicated large heterogeneous variabilty among samples. Heterogeneity beyond that expected from a Poisson distribution may have contributed to the variability of data points around the curves as, for example in $\mathrm{C}_{4}, \mathrm{C}_{7}-\mathrm{C}_{10}$.
In most sampling situations, the mean count from a sample consisting of 100 sampling units would have relatively small variance, and would be a good predictor of actual abundance. The fact that there was heterogeneity above the Poisson level implies that the variability among individual counts was extremely large. In general, variability was least for net sampling, higher for container sampling, and very high for D-Vac sampling (Table 5). It is possible that D-Vac sampling, holding the apparatus just above the plant canopy, is harder to perform consistently. For this reason, we paid less attention to the D-Vac results.

Future work on estimating density of Anthonomus sp. would need to consider these and other complications. For example, A. pomorum displayed predominantly nocturnal behavior patterns in both laboratory and field studies (Duan et al. 1996). Therefore, for such species, the numbers of individuals that can be sampled on the plants during the day may not represent a constant proportion of the true population, thus increasing sample variability.

Pest Management. For the cultivars examined here, harvest takes place approximately between 950 and 1,500 DD (Mailloux and Bostanian 1991), so the bud weevil affects harvest only through its 1st generation. Figs. 2-5 and Table 3 show that the spring generation attains maximum abundance anywhere from 500 to $670 \mathrm{DD}$ above $0^{\circ} \mathrm{C}$.

The results in Table 4 suggest that control measures based on degree-days can be effective in maintaining weevil populations at low numbers and thus reduce berry loss. A summer treatment after harvest is an interesting concept and the results shown here look promising but further research needs to be done. If such a pest management program becomes viable, it means that no pesticides would be needed against this pest before the berries are picked, and several insecticides that cannot be used currently because of residue considerations could then be used without much concern, because these would be applied a year before harvest.

A pesticide intervention may not always be necessary, especially in the 1st yr of harvest. However, for the 2 nd yr of harvest, the results of this study indicate that the optimal time of chemical treatment to control the strawberry bud weevil is between 500 and $670 \mathrm{DD}$ above $0^{\circ} \mathrm{C}$ calculated from 1 April. The beetles may be sampled either by sweeping or tapping into carton box of $500-\mathrm{ml}$ capacity. The percentage of clipped buds after treatment carried out in that interval of time would be commercially acceptable to growers. Unfortunately, a relationship between weevil numbers and clipped buds (harvest loss) does not exist. Such a relationship is a prerequisite for establishing an action threshold based on pest abundance and a sampling program.

\section{Acknowledgments}

Agriculture and Agri-Food Canada Contribution No. is 335/99.04.21R at The Horticulture Research and Development Center, St. Jean-sur-Richelieu, QC, Canada. 


\section{References Cited}

Abramowitz, M., and I. A. Stegun. 1972. Handbook of mathematical functions. U.S. Department of Commerce, National Bureau of Standards, Washington, DC.

Baskerville, G. L., and P. Emin. 1969. Rapid estimation of heat accumulation from maximum and minimum temperature. Ecology 50: 514-517.

Cockfield, S. D., S. M. Fitzpatrick, K. V. Giles, and D. L. Mahr. 1994. Hatch of blackheaded fireworm (Lepidoptera: Tortricidae) eggs and prediction with temperaturedriven models. Environ. Entomol. 23: 101-107.

Clarke, R. G., and A. J. Howitt. 1975. Development of the strawberry weevil under laboratory and field conditions. Ann. Entomol. Soc. Am. 68: 715-718.

Dorval, P. 1938. Les ennemis du fraisier. Rev. Oka 12: 1-10.

Duan, J. J., D. C. Weber, B. Hirs, and S. Dorn. 1996. Spring behavioral patterns of the apple blossom weevil. Entomol. Exp. Appl. 79: 9-17.

Genstat. 1996. Genstat for Windows. NAG, Oxford, UK.

Kempton, R. A. 1979. Statistical analysis of frequency data obtained from sampling an insect population grouped by stages, pp. 401-418. In J. K. Ord, G. P. Patil, and C. Taillie [eds.], Statistical distributions in scientific work. International Cooperative, Burtonsville, MD.

Kovach, J., W. Wilcox, A. Agnello, and M. Pritts. 1993. Strawberry IPM scouting procedures: a guide to sampling for common pests in New York State. IPM No. 203b. Cornell Cooperative Extension, Cornell University, Ithaca, NY.

Mailloux, G., and N. J. Bostanian. 1991. The phenological development of strawberry plants and its relation to tarnished plant bug seasonal abundance. Adv. Strawberry Prod. 10: 30-36.
1993. Development of the strawberry bud weevil (Coleoptera: Curculionidae) in strawberry fields. Ann. Entomol. Soc. Am. 86: 384-393.

Manly, B.F.J. 1990. Stage Structured populations, sampling, analysis and simulation. Chapman \& Hall, London.

Mathsoft. 1995. Mathcad PLUS 6.0. Mathsoft, Cambridge, MA.

McCullagh, P., and J. A. Nelder. 1989. Generalized linear models, 2nd ed. Chapman \& Hall, London.

Niemczyk, H. D., R.A.J. Taylor, M. P. Tolley, and K. T. Power. 1992. Physiological time-driven model for predicting frst generation of the hairy chinch bug (Hemiptera: Lygaeidae) on turfgrass in Ohio. J. Econ. Entomol. 85: 821-829.

Paradis, R. O. 1979. Essais d'insecticides contre l'anthonome du fraisier, Anthonomus signatus Say, présent conjointement avec la punaise terne, Lygus lineolaris (P. de B.) dans des fraisières. Phytoprotection 60: 31-40.

Pritts, M., M. J. Kelly, and G. English-Loeb. 1999. Strawberry cultivars compensate for simulated bud weevil (Anthonomus signatus Say) damage in matted row plantings. Hort. Sci. 34: 109-111.

Rivard, I., G. Mailloux, R. O. Paradis, and G. Boivin. 1979. Apparition des adultes de l'anthonome du fraisier, Anthonomus signatus Say, en fraisiéres et framboisiéres au Québec. Phytoprotection 60: 41-46.

Schaefers, G. A. 1978. Efficacy of Lorsban brand insecticides for the reduction of strawberry "bud" weevil, Anthonomus signatus Say, damage in stawberries. Down Earth 35: 1-3.

Received for publication 8 April 1998; accepted 9 February 1999. 